\title{
Action Telling method : From storytelling to crafting the future
}

\section{Kangas, Jonna}

Springer

2019

Kangas , J \& Reunamo , J 2019 , Action Telling method : From storytelling to crafting the future . in K J Kerry-Moran \& J-A Aerila (eds), Story in Children's Lives : Contributions of the Narrative Mode to Early Childhood Development, Literacy, and Learning . Educating the Young Child, vol. 16 , Springer , Cham , pp. 113-128 . https://doi.org/10.1007/978-3-030-19266-2_7

http://hdl.handle.net/10138/307750

https://doi.org/10.1007/978-3-030-19266-2_7

unspecified

acceptedVersion

Downloaded from Helda, University of Helsinki institutional repository.

This is an electronic reprint of the original article.

This reprint may differ from the original in pagination and typographic detail.

Please cite the original version. 
Chapter 7.

Action Telling Method: From Storytelling to Crafting the Future

JONNA KANGAS

University of Helsinki

jonna.kangas@helsinki.fi

JYRKI REUNAMO

University of Helsinki

In this chapter, we describe the Action Telling method and how it supports young children in exploring their ideas for how to react in challenging social situations. Action Telling is an active storytelling method that focuses on children's conceptions of their initiatives, interactions, decisionmaking, and the dilemmas they face in Early Childhood settings as it promotes children's agency and meaningful problem-solving. In the Action Telling method, teachers facilitate children's participation to bring out their ideas and describe their personal ways of solving issues in everyday social activity with peers and teachers. In this chapter, the Action Telling method practices are introduced for teachers who are interested in understanding children's ideas and perspectives and supporting children's participation and agency. The ways in which children's participation enhances social and cognitive development are explored as well as children's development of reasoning skills, logic, and reflection, which are essential for creating innovative ideas and knowledge, and in the end, new interaction.

Keywords: Participation, Action Telling, Narrative approach, Agency 


\section{Action Telling Method: From Storytelling to Crafting the Future}

\section{Introduction}

A group of children in an Early Childhood classroom sit in rapt attention as their teachers role play a scenario in which a child, Ipa, teases and interrupts another child, Lela, in her play. Two teachers act out the storyline but change their actions according to the children's ideas about how Lela should behave to solve the dilemmas she faces in her kindergarten class.

The blue toy was Lela's favorite in the classroom. She was building her own sea home inside a little box. It helped with her sadness about being away from home. Lela put in there all the finest belongings and most exciting treasures. Lela put some sand on the bottom of the box because she liked sand most of all. A floor was not needed. What use would a floor be to a fish? Lela's own favorite place in her sea home was floating near the ceiling from where she could see everything. The seaweed could scratch her tummy. Lela invited Hanna to join her to play. They observe the sea shells as fish would do.

Suddenly, Ipa comes and disturbs Lela's and Hanna's play. Ipa tries to take away the sea shells that Lela and Hanna are playing with. Lela cannot play peacefully when Ipa keeps interrupting her play."

One teacher is the storyteller and claps her hands to signify her role: What does Lela do now? What do you think? The play is stopped just when it is at its best. Who can guess?

$I^{\text {st }}$ Child: I do not know.

$2^{\text {nd }}$ Child: Drive him out! (the child waves his hands in the air and seems to push Ipa away).

The storyteller claps her hands again and the story continues following the child's idea of driving the bully away. Lela tries to push Ipa away. Happy play begins again, but after a while Ipa comes back. This time he tickles Lela.

The storyteller claps her hands and the situation freezes: It did not help! Ipa comes again.

Child: Oh no.

Child: Maybe we can make a plot ...

Child: Lela can disturb him back ...

Storyteller: Lela can disturb him back. With a clap of the hands, the story continues. Ipa comes again to disrupt, but Lela stands up and goes after Ipa and teases Ipa.

The situation is becoming chaotic. Children scream in protest. The storyteller claps her hands: It did not work. They begin to fight! What now?

Child: Have to ask: "Can you stop teasing me?"

Child: Ask him nicely.

The storyteller claps her hands: Ask him nicely.

Lela goes and tries to discuss nicely, but Ipa will not listen. Ipa shakes his head.

Many children stand up excitedly and give orders to Ipa and advice to Lela.

Storyteller: Oh boy, even that did not work. How can we stop the disruption?

Child: Lela must say that he can play with them.

Child: Yes!

Child: Ipa has nothing to do; he has no friends!

Child: They can play together!

These young children and their teachers are using the Action Telling method to explore social relationships in their classroom. Consider the role of the children as the Action Telling story unfolds. They have different ideas about what do, how to solve the emerging problem. Children's ideas are discussed; they are acted upon and tested. Some of children's ideas work well and some do not, but the development of the storyline depends on the children's initiatives. What do you do when you are happily playing with your friend and someone comes to disturb and tease you? Each child's strategy and point of view has different consequences, and all are enacted through the Action Telling method to help the children to explore different solutions and their outcomes. When children's ideas have consequences 
that they can see acted upon, children learn diverse approaches to taking each other's feelings into account, solving problems, and influencing their everyday life in educational settings.

In this chapter, the method of Action Telling is explained with its aim to understand young children's conceptions about the initiatives, interaction, decision-making, and social dilemmas they face daily in Early Childhood Education settings. Through the Action Telling method, children's ideas can be considered when choosing activities (Lastikka and Kangas 2017; Reunamo 2001). We begin by describing the Action Telling method followed by its theoretical basis. Next, we discuss the results of research with young children using the Action Telling method and describe how this method was implemented in a pedagogical context by returning to the Lela story used in the introduction. Finally, we describe a four-phase process for teachers using Action Telling in the Early Childhood classroom.

\section{The Action Telling Method}

Research has shown that when children's ideas are listened to and their initiatives change the situation in pedagogical activities, they experience participation (see Kangas 2016; Berthelsen 2009). Participation means that children realize their voices are heard and their interpretations can change the course of actions (Ba, 2009; Woodhead 2006) Through participation, their agency develops as they learn to take responsibility and join in shared decision-making processes (Kangas, Ojala and Vennine, 2015; Kumpulainen et al. 2011). To focus on children's conceptions about the teachers' role as an enhancer of shared and common action, new methods of listening to children's conceptions and experiences of their daily life in educational settings are required. For example, Karlsson (2012) suggests using the Storycrafting method, in which value is given to stories freely crafted by children without adults interrupting. In the Storycrafting method, children are encouraged to freely tell any story that they want to share with teachers or their peers (see Chapter 7). In early education, young children have experiences through actions and instead of verbal telling, they communicate with actions and initiatives (Leinonen and Sintone 2014).

The Action Telling method (Cheng, et al. 2015; Reunamo 2001) is a method in which a child is presented with everyday social situations through storytelling role play or with the help of pictures and images and describes what he or she would do in a similar situation. Through this method children daily experiences can be created as everyday stories, that will also support children to regulate their behavior and create their future through agency. The method has been used since 1997 (cf. Reunamo 2001) and was created to understand the perspectives of 3- to 7-year-old children in Early Childhood Education settings. Younger children are also viewed as competent actors in their toddler groups, but they may lack skills to verbalize their actions; therefore, we do not suggest using the Action Telling method with them. In the method, children's views about their agency and their evaluation of the potential change in the situation are connected with their actions. It has also been a valuable tool for studying and understanding children's participatory and other major orientations like adaptation, dominance or withdrawal. The method is available to teachers, social workers and researchers who wish to understand children's actions in classroom settings and through that, scaffold them to use their participatory skills for success.

In the sample story about Lela and Ipa, the teacher/storyteller focused on children's initiatives, and by including them as part of the storyline, she gave the children the experience of seeing how their actions might influence the outcome. In this method, children's narrations about their actions are considered as stories of their everyday life. Through the Action Telling method, adults can scaffold children to learn about the consequences of their actions.

For example, a child who is too shy to take action or independent initiative about play with her peer can learn to express her ideas and initiatives to the teacher through the storytelling. The teacher can support her to take the same action with her peers. Thus, children's views change the actions in the unfolding drama and create learning experiences about social actions and problem-solving situations. Social skills are practiced and learned through interaction, but stories facilitate and model children's 
conceptions about appropriate social behavior (Bae 2009). Through stories, children can learn the consequences of good manners or unruly behavior. Adults can support children to build bridges from experiences to stories and discuss the outcome of positive social actions, such as sharing toys, being polite, or inviting peers to join in play (Kumpulainen et al., 2011).

\section{Theoretical insights on the Action Telling method Image of a child}

The image of a child is a conception that is based on the values and beliefs of adults who have children in their everyday life, such as parents and teachers. Brownlee (2009) describes the values and beliefs that shape adults' understanding of children's competence. It is based on an ontological understanding of childhood and holistic learning. This viewpoint is known as the whole child approach (Slade and Griffith 2013; Liew 2012) in which children are viewed as active learners, agents of their lives, and interpreters and reproducers of culture (Corsaro 2011; Piaget 1976; Rogoff et al. 1995). The guidelines for this whole child approach are introduced in the sociological research; participation is considered from the point of view of decisions and events of children's life (Corsaro 2011; Woodhead 2006). This approach has been adopted widely in the research on Early Childhood Education since Piaget's (1976) and Vygotsky's (1978) theories of learning and has found support in other disciplines such as sociology (Corsaro 2011), developmental psychology and cultural studies (see Berthelsen 2009). The aim of this approach is to study and understand children as subjects of their own lives and not the object of education; participation is considered as a dynamic and evolving concept of individual and shared competence, rather than a child's property or a stable status quo (Kangas 2016; Smith 2002). Thus, participation is related to a contextual social environment and culture, including interaction, shared meaning-making, and everyday experiences in children's lives (Berthelsen 2009).

Children's participation in their early years has been a research theme internationally during the past decade. Rather than viewing children as isolated actors in their social and cultural environment, the more general view of participation considers children as active subjects interacting with other people and the environment (Kangas 2016; Smith 2007). This view of children as competent actors and active agents, rather than as needy and helpless beings (James and James 2012) has been adopted as a part of educational ideology (Kronqvist and Kumpulainen, 2009; Berthelsen 2009). With this learning paradigm, the question of children's participation is a key aspect of both education and research.

Young children's participation in educational settings is a multidimensional issue, where the key elements are well-being and active competence (Brownlee 2009; Sheridan and Pramling Samuelson 2001). This research is based on the knowledge of learning through the socio-cultural paradigm, in which children are competent actors and active agents who construct their development path through shaping, sharing, and reproducing their learning (Kronqvist and Kumpulainen 2011; Rogoff et al. 1995). The concept of learning in Early Childhood Education can be viewed as a dynamic process through which children merge into the culture of their society, its practices and values through active meaning making (Kumpulainen et al. 2011). Further, children's social skills and understanding of the consequences of their actions develops.

However, children's viewpoints are not considered enough in education or research because of the lack of participatory methods for focusing on children's everyday experiences and views. For example, by interviewing 5- to 6-year-old preschoolers or observing them in educational settings, Sheridan and Pramling Samuelsson (2001) and Bae (2009) have found out that children face restrictions based on adults' beliefs and the cultural traditions of educational institutions. Children's chances to have influence or inform adults about their perspectives and ideas have been also found to be limited and appear only in issues related to play-based activities. Sheridan and Pramling Samuelsson (2001) point out that through children's experiences, it is possible to reach toward their world. Children have real influence when they are seen and heard, and their intentions are interpreted by adults who respect children (e.g., Venninen and Leinonen 2013). The goal of the Action Telling method is to understand how children consider their own participation in learning practices, everyday activities, and joint meaning making. 


\section{Narrative approach: Focus on the experience}

When children are regarded as the experts of their own lives, appropriate strategies are required to understand and value their perceptions (Tay-Lim and Lim 2013). The international discussion about finding and developing suitable methods for understanding young children's perceptions and creating learning experiences based on children's interests has been the topic of several studies focusing on listening to children (e.g., Karlsson 2012; Crivello et al. 2009). Clark (2011) states that in the research about participatory methods, the debate has shifted from presenting cases of listening to children's perspectives towards supporting their involvement in the learning processes.

The Action Telling method is based on the narrative approach through which the world and knowledge are built through stories that describe the experiences from the past and show intentions towards the future. Listening to and understanding children's conceptions about actions they would and could take in the form of stories is one way of acknowledging children as active agents of their life stories (Clandinin et al. 2006). In this method, we view children's conceptions through their own past and future actions, ideas and aims in educational settings as shown through their stories. These narrations, considered as representations of experience, can be seen to give meaning to personal experiences and thus, to construct personal relationships with others, the environment and educational settings (Ahn and Filipenko 2007). Spakers and Smith (2008) have noted that through narration, children can be supported to make their conceptions about their relationships, interactions, and social skills with others visible. The narrations build the image of self, support children in focusing on their competences and actions in everyday life and help them and others to understand how they view their role and status in society (Ahn and Filipenko 2007). Later, between similarities and differences of children's views and teachers' conceptions, it is possible to create an understanding of children's roles in the classroom and reflect on the development needed to increase the quality and wellbeing of children in Early Childhood Education settings. Through the Action Telling method, the focus of practical education can be aimed towards empowering participation and teachers can focus supporting children's development through participation and agency in decision making and shared meaning making processes.

\section{Research Outcomes of the Action Telling Method}

Research with the Action Telling method focuses on children's views, interpretations, and ideas as well as its effectiveness on enhancing participation in Early Childhood settings.

For example, the Action Telling method described in this chapter was used as tools for collecting data in 2013 with 153 children aged 3.5 to 7 years and representing nine Early Childhood Education classes in the Capital area of Finland. Through the use of Action Telling, we strived to understand children's conceptions about their chances to participate, use power, and have influence in an educational institute. The analysis of this data showed:

- Children's participation grows when their needs are fulfilled;

- Participation can be experienced through independent initiatives;

- Children are provided with safety and care, but also opportunities to learn;

- Children can experience that the courage to express themselves has positive effects on themselves and others;

- Participation is also making choices, taking responsibility, and taking part in decisionmaking;

- Children are part of home, peer culture, society, and current events;

- Children have the right to enjoy themselves with others who enjoy their company (Venninen and Leinonen 2013). 
Based on the results of Venninen's and Leinonen's research (2013), we asked an artist to draw pictures to express the issues of children's participation in kindergarten (age 7) for further use. Picture 1 is a representation of a situation in which a child could make a choice and take responsibility.

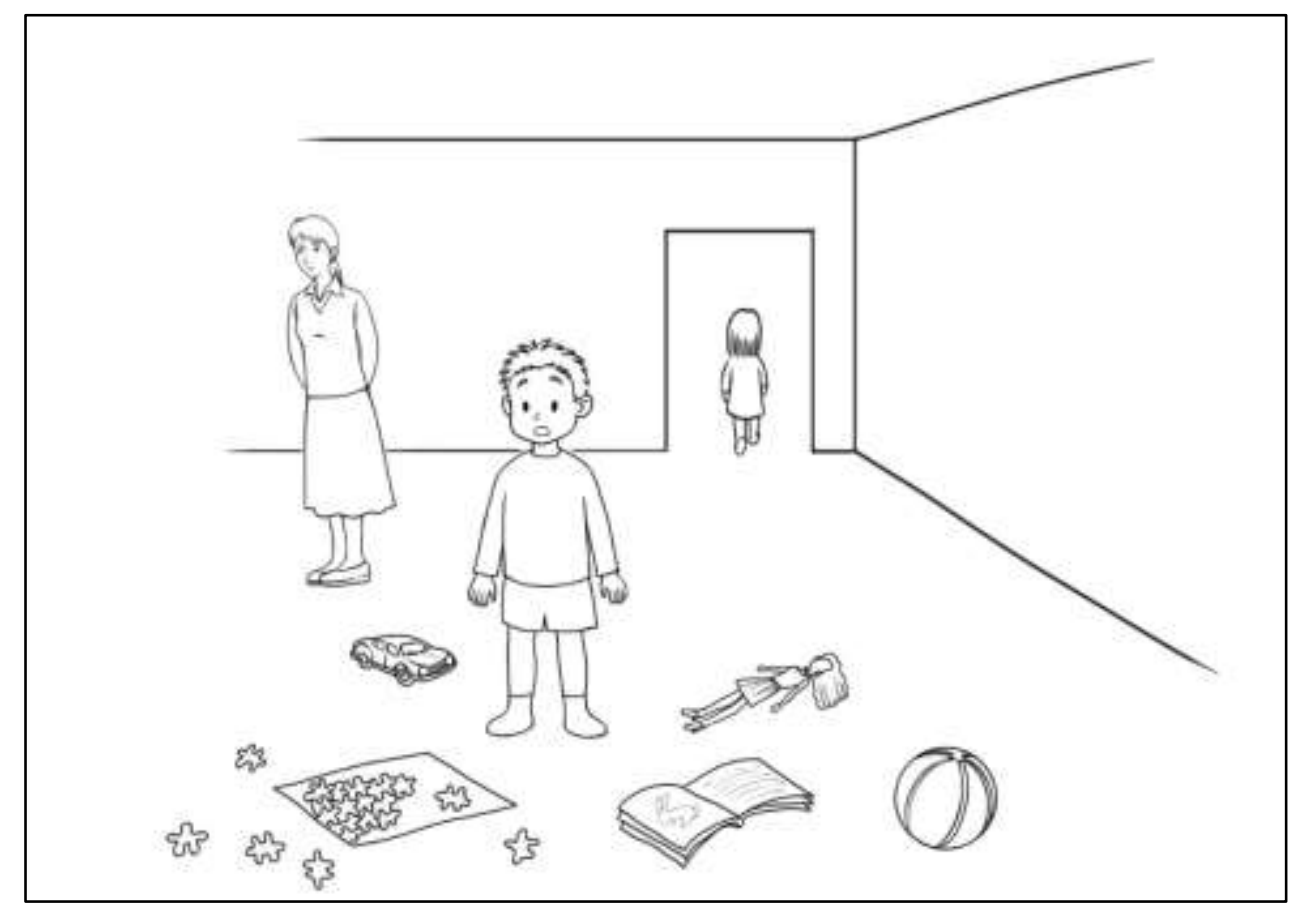

Picture 1. Participation is also making choices and taking responsibility.

These pictures were also tested (Leinonen 2013). We showed this picture (Picture 1.) to children and by the guidelines of the Action Telling method asked the child to describe his or her initiatives and actions by saying, "You are here; what would you do?"

The analysis of the children's ideas and interpretations based on this individual picture showed that children used three different storylines. About $40 \%$ of the children thought the boy in the front had had an argument with the girl in the back of the picture. The girl was leaving, and the boy would like to solve the situation. The children suggested that the boy could either ask for the teacher's help or run to the girl and apologize. The stories followed individual paths, and children added different items and events to form a holistic story about the picture. Children's responses were given in Finnish and translated into English by the researchers.

They have been playing together, but suddenly he notices that the others have gone away. He feels bad about being alone but started to finish to a jigsaw puzzle that she has left behind. But then she comes back and observes that her puzzle is ready. And she burst in tears, because she would like to finish it herself. The boy feels bad and says: "Could we make this puzzle again together?" and she smiles and says: "Yes, let's do it!" and they have made it up. (Peppa, 6 years and 5 months)

The other explanation (about $38 \%$ of the children) for this situation was that the boy was playing here, while the girl came in and suddenly messed with his toys and ran away. Children who had this interpretation agreed that the boy would feel bad and the girl should come back, apologize, and help him to fix the toys. Some children would add that after that, they could play together.

Once upon a time there was a happy boy called Oscar. He was playing with a puzzle. Suddenly, a girl named Emily came in and kicked his puzzle and it was shattered around; Oscar wondered why Emily did so. The teacher looked at Emily and asked, 'Emily, why did you kick the puzzle?' 'I want to play with Barbie dolls and Oscar's puzzle was in my way' said Emily. The teacher said that it was not nice behavior, but Emily did not care. She sat down to read a book with Oscar, but Oscar was angry and shoved her, so that she fell down on the big ball. Then the teacher said: 'You are both 
behaving badly; please apologize to each other so you can continue to play.' Oscar would have agreed, but Emily said, 'First, I want to read this book with bunnies.' (Irina, 5 years and 10 months)

This boy is building his puzzle when that girl there comes and messes with it, and the pieces scatter all over the place. And then the girl went away with her doll and he thinks that he must ask her to come back and apologize. Finally, he finds her, and she apologizes. (Mona, 5 years and 2 months)

The third storyline was from about $15 \%$ of the children who said that the boy and the girl were playing together, but then the girl's mom came, and she had to leave for home. After that, the children either described how the boy had to clean the mess by himself, or they suggested that he could ask the teacher to join the game with him.

He felt that the puzzle was soooo difficult. Oh no, I can't build this, he thought. He went to ask the teacher, 'Can you help me?' The teacher smiled and answered, 'How about if you ask that girl who is also alone to help you?' And so, he did and she joined him and helped with the puzzle and it was easy peasy... And after that they read a book together and played with toy cars and Barbie dolls. (Vera, 6 years and 9 months)

All the storylines highlight a positive viewpoint and outcome; children expressed joy, a feeling of belonging and friendship towards their peers. They were also considering social rules that are important to follow to "not to make the other child feel bad;" finally, children expressed a strong belief that the teachers listened to them and were interested in their initiatives and willing to join their activities (see Leinonen 2013). Children's actions in the Early Childhood Education context are guided by their understandings and beliefs. The question is not whether the children have agency but how teachers can enter a dynamic process to help the child consider how to react in social situations. Are they able to support children's participation to help them develop as competent agents? We believe that through the Action Telling method, teachers and researchers can understand children's views about their actions; thus, they can create ways to scaffold children in their developing agency and process of social development and participation.

\section{Action Telling in an Early Childhood Classroom}

The Action Telling method can be used to listen to children's ideas and make room for them to influence their everyday activities. In Lela's story (the introductory story), Lela's responses were determined by the children; their ideas affected the plot of the drama and the outcome of the story. Children's ideas and interpretations have an effect on peers and adults around them as well as on everyday activities in their lives.

In this section, we present interpretations of the children's responses to Lela's story and how these interpretations can inform teachers about children's social and emotion development levels and needs. Our aim is to highlight how the communication within the story relates to real life. Children's comments about their ideas are associated with their everyday activities and interactions with other children. Thus, children's descriptions can influence activities as they occur, such as conflict resolution in the classroom. The introductory included only a sampling of children's comments and do not represent all the ideas and responses of children that emerged during our Action Telling research.

Children's ideas through the Action Telling method are connected to their actions (see, for example, Reunamo, Ko, Cheng, Lee, Wang and Salminen 2016). In Lela's story, children could express different ideas about the actions they would have taken towards teasing by a peer in the classroom. The research findings suggest that most of the children's ideas can be classified as "participatory," meaning that they tried to resolve the conflict by communicating with other children and adults. We learned that experiences of participation increased with age, and that girls expressed more (73\%) participatory descriptions than boys (68\%). Participatory ideas in the Lela story were: 
Again, I tell the teacher.

"Could you stop, please?"

You have to tell your friend.

I say "Stop, this is not funny."

"Do not run after me."

I say, "Don't do that; I will start to feel bad."

Children who gave participatory ideas were observed to play more role plays with their peers. This indicates that creating and interpreting imaginary worlds and settings (i.e., participating in role play) may also relate to constructive participation in another context (i.e., from constructing solutions to problem-solving situations and social dilemmas). Children whose ideas were classified as participatory attended toward another child, initiating more social contact with others. However, the more open and dynamic the situation was, the more teasing experiences happened (Reunamo, Ko, Cheng, Lee, Wang and Salminen 2016). This indicates that young children are not yet able to avoid conflicts; therefore, the Action Telling method offers parents, teachers, and other adults a window on children's play and peer relations and enables them to support children to become more empowered with their social skills through stories.

Some of children's ideas for the dilemma in Lela's situation were classified as "withdrawn" ideas. Overall, Action Telling situations demonstrating teasing or bullying between children had more instances of withdrawal than other situations. In withdrawn ideas, children do not try to change the bully's behavior, but rather choose to exit the situation themselves, as in the following examples:

I will go away and tell the teacher.

I have to leave.

I will be by myself.

I will run away.

I will go to mother. I will go to an adult.

I will play alone.

In these examples of withdrawal, the children do not process the situation; rather, they avoid it. Withdrawn ideas are more common among younger children, while older children are eager to solve the situation. Children with withdrawn ideas also tended to describe other situations in a more withdrawn manner, indicating a general mode used to consider issues or challenges by withdrawing (Reunamo, Ko, Cheng, Lee, Wang and Salminen 2016). With withdrawn children, the Action Telling method offers an opportunity to practice social and participatory actions toward others. By repeating the situation with children and suggesting different responses, a teacher can encourage a child with withdrawn ideas to become more confident and practice other ways of solving some social problems with peers. Some children had dominant descriptions in which they expressed teasing back or forcing the bully to change behavior:

I would push him far away.

Then I would tease him back.

I would hit him.

If Hans hit me; I would tease Hans.

I would fight.

I would tease him.

In the dominant descriptions, children describe their ideas about changing the bully's behavior. Only $5.1 \%$ of the descriptions were dominant, although dominant ideas decreased as children aged. Boys described more dominant actions than girls (Reunamo, Ko, Cheng, Lee, Wang and Salminen 2016). It may be that the dominant strategy is maladaptive. Children with dominant descriptions attended less non-socially and more towards other children.

In the study, children rarely described an accommodative response where they did not find any solution to the conflict in the Lela story: 
I do not care.

But in reality, it does not hurt. It does not look like he is hitting.

I do not fight back

Then he will always tease me.

Then I will be in stupid clothes.

I will be left in peace

Accommodation is sometimes a positive strategy or idea towards a situation and represents sensitivity and flexibility, but in the teasing situation, as in the Lela story, it may result in passivity and inactivity. Considering age, children's strategies tended to become more adaptive as they matured. At the same time, their agency for seeking alternate solutions increased. The general trend moved from enduring the unpleasant situation to seeking alternatives. Younger children in particular may only see the option to obey (Reunamo and Hällström 2013).

Children's ideas do change the course of events and in different activities in which they take part during their everyday life. Children also learn during these activities; therefore, it is worthwhile to embed children's ideas in the unfolding story through Action Telling. Stories are not just stories; they may also give teachers insight into children's development. When a child is asked, "If somebody comes to tease you, what do you do?", the child's response should not be considered in the axis of a right or wrong answer; it should be used to learn the options the child considers. When teachers understand children's thinking, they can support them in developing more effective social and emotional responses.

\section{Implementing Action Telling method in the Early Childhood Classroom}

In the Action Telling process, children are invited to tell about their conceptions regarding everyday interactions and problem-solving situations. This storytelling process is guided with role play or simple pictures and the problems are related to everyday situations where bad behavior, arguments or disagreements can exist. Through storytelling, children use their competence and social knowledge about good manners, friendship, problem-solving and joint meaning-making to find suitable solutions to the presented problem. From these stories it is possible to discover children's understanding about their competence to solve problems, skills to do so, and conceptions about belonging and interacting with others (peers and teachers) by following how the children describe their roles and the roles of others. The answer also describes the consequences of the children's strategies in various social situations.

Next, we will describe the phases of the Action Telling practice for using the method in the classroom.

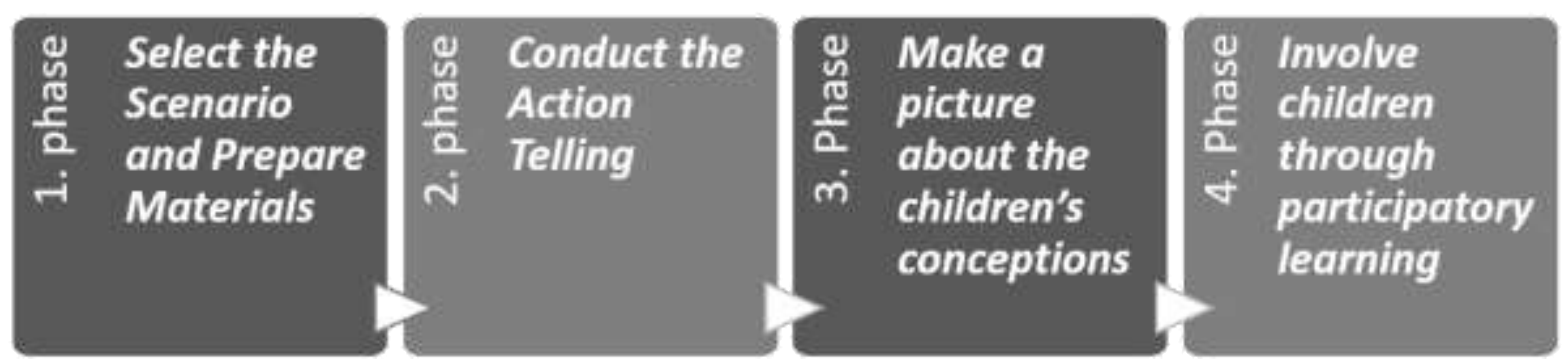

Figure 1. The Action telling method phases

\section{First phase: Select the Scenario and Prepare Materials}

Determine the social situation or problem to be explored with the children and prepare the needed materials. These materials might include a picture depicting a situation (See Picture 1) or a problem to be acted out like the conflict between Lela and Ipa depicted at the beginning of the chapter. Pictures 
can be drawn or printed from free online resources and storylines can be created based on children's needs. Determine whether to use the method with a group of children or individually.

Review the storyline and consider which questions you are going to ask to encourage children to tell their ideas and interpretations. Avoid questions that allow children to give only one kind of answer and questions that allow 'yes' or 'no' responses. Remember that you want to listen to children's ideas and honor their personal interpretations.

\section{Second phase: Conduct the Action Telling}

The Action Telling should take place in a peaceful environment that is appropriate for the child's age, language ability, and personality; for example, some children may need more time or different ways to express themselves to understand and answer the questions. We have found out that some children feel uncomfortable at the start of the Action Telling situation, if they are not used to the notion that an adult really wants to hear their thoughts and ideas. In this case, ask the child to come and play with you for a few minutes before beginning the Action Telling process. In our experience, through play, children felt more relaxed and began to describe their everyday life (see Lastikka and Kangas 2017).

If you are using pictures, sit with the child side by side and look at the pictures together and say: "I would like to read a book, which is about you. This book is unfinished; all the words are missing, and I need your help in completing the story. Could you help me?" With each picture, the adult asks the child to explain any action he or she would take in that situation: "If you were the child in the picture, what would you do? I would like you to tell me what you would do on each page and I will write it down for you. Are you ready to begin?" This question aims the child's focus at solving the presented problem of a challenging situation. The child answers by telling a story, which is recorded.

While asking children to tell their story about the picture, questions such as "What happened?" should not be used. All the children who participated in the Action telling research in 2012 interpreted 'happened' to indicate rule breaking and other negative issues in kindergarten. Therefore, it was important to use verbs like 'do' and 'make.' "What are you doing here?" was always a gentle encouragement towards the child's action.

Teachers also should not provide examples or otherwise ask leading questions during the Action Telling process. It is also important that they never complete children's responses in a sentence. If the child answers with one word, or the answer is incomplete, they should ask again, "What will you do?" or "Tell me more of what you are doing." Sometimes the child does not describe his or her action but focus more on describing the picture. The adult could then ask again; for example, if the child says, "The teacher is angry," the interviewer can say, "OK, the teacher is angry; what do you do then?"

The approximate time for the discussion about the pictures is usually between seven and fifteen minutes. Most of the children in our studies were not willing to continue much longer than that. A child's first answer describing his or her action should be written down immediately. However, sometimes the child is telling a story about what happens first and what follows (see Lastikka and Kangas 2017). A child can be gently encouraged to continue describing ideas and interpretation of the situations in the pictures.

If you choose to use teacher role play with a story such as the Lela and Ipa conflict narrated at the beginning of the chapter, children may sit in a circle on the floor. When the storyline creates a chance for a discussion or you are asking the children for their ideas, put down any materials you are using to express that you are ready to listen to their interpretation and are not in a hurry to continue the story. 
For a longer storyline, avoid bringing too many situations to children during one Action Telling moment. Let the children focus on one or a maximum of two situations at a time. You can continue Action Telling with the familiar characters (such as Lela); thus, you will facilitate children's ideas and telling in a long-term process.

It is important to include both individual and group activities to the Action Telling method. When children can mix their own ideas with others in a shared process, an enlarged zone of proximal development occurs (Vygotsky, 1978); thus, children may join in a shared meaning-making process that is essential for socio-cultural learning (see Kumpulainen et al. 2011). Furthermore, their learning will be scaffolded (Kangas 2016).

Some children need encouragement to answer. For example, if the child says, "I don't know," the situation can be described in other words. In the end, if after encouragement, the child still says, "I don't know," that is also an acceptable response and it is written down. Children who do not find ways to use participatory descriptions in the Action Telling situations can face challenges joining play activities or making joint decisions with their peers; they may need support by parents or teachers to learn new strategies and skills.

Finally, we have incorporated a package for teachers and parents to test the Action Telling method. The package is available for parents and teachers online (see Reunamo 2015) and it includes thirteen different scenarios that can be used as platforms for participatory storytelling.

\section{Third phase: Make a picture about the children's conceptions}

After the storyline or picture assignment, it is time to compose a summary of the children's stories to understand what kind of conceptions about social actions have been presented in your class. Read all the children's stories and take notes about the competence of children to solve problems. Are there some children who are more advanced in social interaction in your class? How about those children who lack skills to regulate their actions, are withdrawn, accommodative, or dominant? Can you find key elements that would describe those lacking skills, or are there social issues (like teasing) occurring? Remember that each child's story is valuable and presents chances for the development of their social skills and competencies. Recreate a storyline using children's ideas and interpretations.

\section{Fourth phase: Involve children through participatory learning}

Finally, it is time to represent the recreated storyline to the children. Remember to tell them that this story is conducted by them. Read the children's stories to them. Leave time for discussion and openended stories, that children can test their conceptions about solving the problem in joint decisionmaking. Use the storyline created by joint meaning-making to support children's development in social situations. Through the story, you can better understand their conceptions and strategies, and you can follow-up with children who do not consider peaceful problem-solving skills, or who withdraw themselves from challenging situations.

\section{Conclusion}

In this chapter, we have discussed the Action Telling method to open children's views of what they do and how they act with peers and teachers. Early Childhood educators can use the Action Telling method to create a participatory environment to support active agency. In our examples, we have used the method in both research and pedagogy. Children's ideas about how to respond in social situations are keys to children's social competence. We focus on the agentive nature of children's views and urge 
all adults to take children's stories seriously and process them together with the young child. As explained the image of the child is created and reproduced by adults - teachers and parents - and thus we see important to give them methods to support children to interpret and reproduce their role through actions. Sometimes, adults have difficulty understanding children's strategies and conceptions of their actions. Therefore, it is important for teachers to support children's development in participatory skills, such as making independent initiatives, taking part in negotiations, and solving-problems Children's identity as competent and capable actors in their social surroundings and later in the society are not the status quo but consist of skills that can be practiced and learned with peers and adults (see Kangas 2016; Sinclair 2004).

It has been shown by Göncu (2009) that these independent skills and competences are not typically part of official school curricula. Children don't produce the learning by using a curriculum or other official documents themselves. Children's agentive power is situated in their relentless and ingenious production of everyday interaction within education practices. Therefore, teachers should support children's development in participatory skills, such as making independent initiatives, taking part in negotiations, and solving problems (Venninen and Leinonen 2013). The Action Telling method is useful in understanding children's views through stories and makes it possible for children's voices to be heard directly, without adults filtering their responses, especially if the stories they tell are written down and repeated.

Finally, the Action Telling method is a tool that creates paths from past to future for children and teachers. When focusing on a story based on lived experience, children can be seen constructing it anew and creating new meanings (Clandinin et al. 2006). When children's ideas have different consequences for the action, children learn diverse approaches to take other's feelings into account, solve problems, and influence their everyday life in educational settings. It is essential that there are different options to solve the problem. Within a shared process, the children can negotiate the situation and try to learn to get along with others. Eventually they develop a dynamic understanding of the world and society through this shared meaning making process (see Kangas 2016; Berthelsen 2009). In this process, the Action Telling method can be considered as a path to understanding children's perspectives and agency.

\section{References}

Ahn, J. \& Filipenko, M. (2007). Narrative, imaginary play, art, and self: Intersecting worlds. Early Childhood Education Journal, 34, 4, 279-289.

Bae, B. (2009). Children's Right to Participate - Challenges in Everyday Interaction, European Early Childhood Education Research Journal, 17, 3, 391-406.

Berthelsen, D. (2009). Participatory Learning, In: D. Berthelsen, J. Brownlee, and E. Johansson (eds.), Participatory learning in the early years: research and pedagogy, New York: Routledge. pp. 1-11.

Brownlee, J. (2009). Context, Pedagogy and Participatory Learning. In: D. Berthelsen, J. Brownlee, and E. Johansson (eds.), Participatory learning in the early years: research and pedagogy, New York: Routledge. pp. 203-208.

Cheng, D., Reunamo, J., Cooper, P., Liu, K. \& Vong, K. P. (2015). Children's agentive orientations in play-based and academically focused preschools in Hong Kong. Early child development and care, 185(11-12), 18281844.

Clandinin, D. J., Huber, J., Huber, M., Murphy, M. S., Orr, A. M., Pearce, M., \& Steeves, P. (2006). Composing diverse identities: Narrative inquiries into the interwoven lives of children and teachers. Routledge.

Clark, A. (2011). "Foreword." In D. Harcourt, B. Perry, and T. Waller (eds.), Researching Young Children's Perspectives. Debating the Ethics and Dilemmas of Educational Research with Children, edited by, xvii-xviii. Routledge.

Crivello, G., Camfield, L. and Woodhead, M. (2009). How Can Children Tell Us About Their Well-being? Exploring the Potential of Participatory Research Approaches within Young Lives. Social Indicators Research, 90, 51-72.

Corsaro, W.A. (2011). The Sociology of Childhood. 3rd ed. California: Sage Publications. 
Kangas, J. (2016). Enhancing Children's Participation in Early Childhood Education with Participatory Pedagogy. Doctoral dissertation. University of Helsinki.

Kangas, J., Ojala, M. and Venninen, T. (2015). Children's Self-Regulation of Participatory Pedagogy in Early Childhood Education. Early Education and Development, 26, 5-6, 847-870.

Karlsson, L. (2012). Lapsinäkökulmaisen tutkimuksen ja toiminnan poluilla [In the Paths of Child-initiated Research and Action]. In L. Karlsson and R. Karimäki (eds.) Sukelluksia lapsinäkökulmaiseen tutkimukseen ja toimintaan, pp. 17-63. Jyväskylä: Suomen kasvatustieteellinen seura.

Kronqvist, E-L., \& Kumpulainen, K. (2011). Lapsuuden oppimisympäristöt - Eheä polku varhaiskasvatuksesta kouluun [The learning environments of childhood-A coherent path from early years education to school]. Helsinki: WSOY.

Kumpulainen, K., Krokfors, L., Lipponen, L., Tissari, V., Hilppö, J. \& Rajala, A. (2011). Learning Bridges Toward Participatory Learning Environments. Helsinki: CICERO Learning, University of Helsinki.

Lastikka, A-L. \& Kangas, J. (2017) Ethical Reflections of Interviewing Young Children: Opportunities and Challenges for Promoting Children's Inclusion and Participation, Asia-Pacific Journal of Research in Early Childhood Education, 11, 1, 85-110.

Leinonen, J., \& Sintonen, S. (2014). Productive participation - Children as active media producers in kindergarten. Nordic Journal of Digital Literacy, 9, 3, 216-236.

Leinonen, J. (2013). Children's conceptions about participation and educators' role as enhancer. Paper presented at the EECERA conference, Tallinn, 30.8.2013

Liew, J. (2012), Effortful Control, Executive Functions, and Education: Bringing Self-Regulatory and SocialEmotional Competencies to the Table. Child Development Perspectives, 6, 2, 105-111.

Piaget, J. (1976). The child's construction of reality. London: Routledge.

Reunamo, J. (2001). You fail. What do you do? Paper presented at the EECERA conference in Alkmaar Netherlands, August 29-September 1, 2001.

Reunamo, J. T., Lee, H-C., Wu, R., Wang, L-C., Mou, W-Y. \& Lin, C. J. (2013). Perceiving Change in Role Play. European Early Childhood Education and Research Journal, 21, 2, 292-305.

Reunamo, J. \& ja Hällström, H. (2013). You do not like the activity arranged by the teacher; What do you do? The European Journal of Social \& Behavioral Sciences (EJSBS), 1050-1056.

Reunamo, J. (2015). Story of Lela. http://www.helsinki.fi/ reunamo/apu/lela.pdf

Reunamo, J., Ko, J., Cheng, D., Lee, H-C., Wang, L-C. \& Salminen, E. (2016). Openness and agency as strategies on addressing bullying. In O. Saracho (Ed.) Contemporary research on bullying in Early Childhood Education. IAP Publishing: USA.

Rogoff, B., Baker-Sennett, J., Lacasa, P., \& Goldsmith, D. (1995). Development through participation in sociocultural activity. In J. Goodnow, P. Miller, \& F. Kessel, (eds.), Cultural practices as contexts for development, San Francisco, CA: Jossey-Bass. pp. 45-65.

Sheridan, S., \& Pramling Samuelsson, I. P. (2001). Children's conceptions of participation and influence in preschool: A perspective on pedagogical quality. Contemporary Issues in Early Childhood, 2, 2, 169-194.

Sinclair, R. (2004). Participation in Practice: Making it Meaningful, Effective and Sustainable, Children \& Society, 18, 106-118.

Slade, S. s., \& Griffith, D. (2013). A whole child approach to student success. KEDI Journal of Educational Policy, 10, 3, 21-35

Smith, A. B. (2007). Children's Right and Early Childhood Education: Links to theory and advocacy. Australian Journal of Early Childhood, 33, 3, 1-8.

Smith, A. B. (2002). Supporting Participatory Rights: Contributions from Sociocultural Theory, International Journal of Children's Rights, 10, 73-88.

Spakers, A. \& Smith, B. (2008). Narrative constructionist inquiry. In J. A. Holstein \& J. F. Gubrium (eds.) Handbook of constructionist research. New York: The Guilford Press, pp. 295-314.

Tay-Lim, J. \&d Lim, S. (2013). Privileging Younger Children's Voices in Research: Use of Drawings and a CoConstruction Process. International Journal of Qualitative Methods, 12, 65-83.

Venninen, T., \& Leinonen, J. (2013). Developing children's participation through research and reflective practices. Asia-Pacific Journal of Research in Early Childhood Education, 7, 1, 31-49.

Vygotsky, L. (1978). Mind and society: the development of higher psychological processes. Boston, MA: Harvard University Press. 
To be published: The Strength of Story in Early Childhood: Diverse Contexts for Development across Domains, Aug 2019

Woodhead, M. (2006). Changing perspectives on early childhood: theory, research and policy, International Journal of Equity and Innovation in Early Childhood, 4, 2, 1-43. 